\title{
"AFRYKA, KTÓRA NADCHODZI". NIE-UTOPIJNA WIZJA PRZYSZłOŚCI W POWIEŚCI ROUGE IMPÉRATRICE LÉONORY MIANO
}

\author{
"The Africa That's Coming": A Non-utopian Vision of the Future in Léonora Miano's \\ Rouge impératrice
}

\begin{abstract}
This article seeks to present the way in which the Afrofuturism as a literary genre can be used to reflect on the potential of the African future. In the novel Rouge impératrice, published in 2019, Cameroonian author Léonora Miano introduces a vision of the future united state of Katiopa which enables her to reconsider some present problems and offered socio-political solutions. The image of the possible future of the African states constitutes a clever and innovative analysis of the current political and cultural issues of the African continent, and its possibilities for a stable and peaceful progress. At the same time, Miano tries to stay clear of the category of Black utopia.
\end{abstract}

Keywords: Afrofuturism, Post-colonialism, African identity, Black utopia

Obejmując pozycje władzy i zaufania, zanim pomyślicie, pozwólcie sobie marzyć1.

T. Morrison

Cytat, który kameruńska pisarka Léonora Miano obiera za motto wydanej 2019 roku powieści Rouge impératrice (Czerwona władczyni) ${ }^{2}$, pochodzi z wypowiedzi

1 Oryg. „As you enter positions of trust and power, dream a little before you think”. T. Morrison, za: L. Miano, Rouge impératrice, Pocket, Paris 2019, s. 7. Jeśli nie podano inaczej, wszystkie cytaty w przekładzie własnym autorki artykułu.

2 Tytuł nawiązuje do jednej z głównych bohaterek powieści, Boyadishi, która po raz pierwszy pojawia się w tekście utworu obserwowana przez Ilungę, prawowitego władcę Katiopy (zjednoczonej Afryki): 
amerykańskiej laureatki literackiej Nagrody Nobla Toni Morrison. W 1988 roku Morrison dedykowała te słowa absolwentom nowojorskiego college'u Sarah Lawrence College w Bronxville, zaznaczając, że „logika nie powinna przeszkadzać w myśleniu o świecie, jaki "powinien być»" ". Dla Miano myśl ta staje się przyczynkiem do stworzenia eksperymentu literackiego o wymiarze politycznym, historycznym, etycznym i kulturowym, w ramach którego proponuje wizję przyszłości kontynentu afrykańskiego zbudowaną na fundamencie skutecznych rozwiązań obecnych problemów społecznych. Perspektywa zjednoczenia i reorganizacji państw afrykańskich w nadchodzącym stuleciu stanowi w przypadku omawianej powieści wynik interpretacji uważnie obserwowanej rzeczywistości oraz propozycję przekroczenia ograniczających uwarunkowań osiągniętą dzięki pracy pisarskiej wyobraźni. Inspirując się afrofuturyzmem, nurtem filozoficzno-literackim, który proponuje różnorodne modele przyszłości Afryki w jej prawdopodobnych i fantastycznych ujęciach, autorka w nowatorski sposób wpisuje swoją powieść w kontinuum afroutopijnych wizji, jednocześnie przekraczając w Rouge impératrice obie z wymienionych kategorii, które krytycy przypisują temu utworowi ${ }^{4}$. Pisarka przyczynia się tym samym do odnowienia sposobów myślenia i fikcjonalnego opisywania tego, jaka „Afryka nadchodzi” lub nadejść może .

Dotychczasowa twórczość prozatorska i eseistyczna autorki urodzonej w 1973 roku w Duali (ang., fr. Douala), a obecnie mieszkającej we Francji, zdradza jej zainteresowanie sposobami tworzenia dyskursów historycznych i opowiadania na nowo

„Stojąc kilka metrów od placu Mmanthatisi, mężczyzna nie mógł oderwać wzroku od kobiety. Znajdowała się w samym centrum, jak słońce, które zachodząc, wdziera swą czerwień przez okna dachów (...). Miała na sobie żółtą tunikę bùbá, co podkreślało czerwony odcień skóry i rudość jej włosów” [oryg. „Debout à quelques metres de la place Mmanthatisi, l'homme n'avait d'yeux que pour la femme. Celle qui se tenait au centre, tel un soleil couchant ayant déposé son rougeoiement sous la verrière (...). Elle portait en tunique un bùbá dont la couleur jaune rehaussait le rouge de sa complexion, la rousseur de sa chevelure". Ibidem, s. 9-15]. Autorka może w ten sposób także nawiązywać do amerykańskiego filmu z 1934 r. pt. Imperatorowa (reż. J. von Sternberg, oryg. The Scarlett Empress), którego francuska nazwa brzmi L'Impératrice rouge. Postać Boyadishi stanowiłaby wówczas polemikę z figurą historycznej władczyni na przykładzie cesarzowej Katarzyny Wielkiej.

3 Oryg. „Logic should not preclude imagining the world as it «ought to be»”. T. Morrison, za: Commencement, „The New York Times”, 28.05 .1988 [online], https://www.nytimes.com/1988/05/28/ nyregion/commencement.html (dostęp: 15.08.2021).

4 Zob. S. Kodjo-Grandvaux, Le grand retour de l'utopie africaine, „Le Monde Afrique”, 23.02.2020 [online], https://www.lemonde.fr/afrique/article/2020/02/23/le-grand-retour-de-l-utopieafricaine_6030544_3212.html (dostęp: 15.08.2021), A. Pétin, La possibilité d'une utopie romanesque pleinement émancipatrice: «Rouge impératrice» de Léonora Miano, „Revue critique de fixxion française contemporaine" 2020, $\mathrm{nr} 21$, s. 95-108.

5 Zarówno wspomniany zwrot, jak i tytuł przedstawianej tu analizy, nawiązują do wydanej w $2013 \mathrm{r}$. w Paryżu antologii opowiadań oraz esejów L'Afrique qui vient. Tom obejmuje teksty obrazujące różnorodność tożsamości i elementów tworzących codzienne życie Afrykanów i afrykańskiej diaspory w XXI w., których autorami są m.in. Léonora Miano, Chimamanda Ngozi Adichie, Mia Couto, Henri Lopes, Hélon Habila, Felwine Sarr. M. Le Bris, A. Mabanckou (red.), L'Afrique qui vient (anthologie), Hoëbeke, Paris 2013. 
(fr. réécriture) z pomijanych wcześniej perspektyw. Jedna z jej najbardziej znanych powieści, uhonorowana w 2013 roku nagrodą Prix Femina La saison de l'ombre ${ }^{6}$ $\left(\right.$ Czas cienia ${ }^{7}$ ), porusza kontrowersyjny temat współudziału przedstawicieli afrykańskich elit w kolonialnym procederze transatlantyckiego i transsaharyjskiego handlu ludźmi. Posługując się badaniami źródłowymi przeprowadzonymi między innymi w Senegalu ${ }^{8}$, autorka ukazała kobiecy punkt widzenia na ten fragment afrykańskiej historii. Zastosowana $\mathrm{w}$ tym celu narracja polifoniczna pozwoliła na poszerzenie kontekstu powieści także o zachowane przekazy ustne dotyczące wewnątrzkontynentalnego handlu Afrykanami ${ }^{9}$ i uprawdopodobnienie fikcyjnej wersji wydarzeń. Tym samym Miano dołączyła do szeregu afrykańskich intelektualistów i literatów, takich jak Étienne Goyemidé, Tierno Monénembo, Florent Couao-Zotti, Patrice Nganang oraz Kangni Alem, którzy stawiają sobie za cel uzupełnianie opowieści dotyczącej złożonej przeszłości kontynentu afrykańskiego także o tematy trudne i niechętnie wysuwane na pierwszy plan w dyskusjach o przyczynach i konsekwencjach sukcesu europejskiego kolonializmu ${ }^{10}$.

W swoim pisarstwie Miano darzy też szczególną uwagą oblicza współczesnej afrykańskiej tożsamości nie tylko z historycznego, ale także społecznego, kulturowego i psychologicznego punktu widzenia. W powieściach takich jak Tels des astres étaints (Jak wygasłe gwiazdy, 2008), Blues pour Élise (Blues dla Elise, 2010), Ces ames chagrines (Te zszargane dusze, 2011), Écrits pour la parole (Zapisane głosy, 2012) autorka przygląda się okolicznościom i odmianom hybrydyzacji kulturowej w życiu afrykańskiej diaspory we Francji, każdą z fikcjonalnych historii rozpatrując w płaszczyźnie indywidualnej, jak i zbiorowego doświadczenia. W wymienionych wyżej tekstach Paryż staje się przestrzenią ,afropejską” (fr. afropéen) i kontekstem tworzenia tożsamości granicznej (fr. identité frontalière). Miano ujawnia w nich skłonność do psychologicznej analizy zarówno konkretnych postaci, jak i relacji partnerskich, rodzinnych, społecznych oraz kulturowych ${ }^{11}$.

L. Miano, La saison de l'ombre, Pocket, Paris 2013.

7 Propozycję thumaczenia tytułu przytaczam za Katarzyną Mroczkowską-Brand, która szczegółowo omawia powieść La saison de l'ombre, umieszczając w swojej analizie obszerne fragmenty tekstu we własnym przekładzie na język polski. Por. K. Mroczkowska-Brand, Deportowani z życia. Nowe głosy $w$ narracjach literackich i ich kolonialne konteksty, Wydawnictwo Uniwersytetu Jagiellońskiego, Kraków 2017, s. 158.

8 Ibidem.

9 Za: R.M. Aguilar, Exhalaisons de la traite et de l'esclavage dans l'œuvre de Léonora Miano, „Woman in French Studies" 2020, nr 8, Special Issue, s. 139.

10 Ibidem, s. 135-136; por. też M.-R. Abomo-Maurin, Préface [w:] A.D. Tang (red.), L'œuvre romanesque de Léonora Miano: Fiction, mémoire et enjeux identitaires, L'Harmattan, Paris 2014, s. 9-10; oraz Ch. Chaulet-Achour, La force du féminin dans «La saison de l'ombre» [w:] A.D. Tang (red.), L'œuvre romanesque de Léonora Miano..., op. cit., s. 18.

11 Kwestię tożsamości afropejskiej w powieściach Miano z tego okresu przedstawia monografia Marjolaine Unter Ecker. Por. M. Unter Ecker, Questions identitaires dans les récits afropéens de Léonora Miano, Presses universitaires du Midi, Toulouse 2016. Zagadnienie identité frontalière w prozatorskiej i eseistycznej twórczości pisarki oraz w tekstach kameruńskiego filozofa Achille 
Chęć zgłębiania i uzupełniania wątków okołokolonialnej i postkolonialnej historii kontynentu afrykańskiego oraz współczesnej afrykańskiej tożsamości doprowadza powieściopisarkę do refleksji nad sposobami, w jakie uwarunkowania historyczne wpływają na teraźniejszość i nad tym, jakiego rodzaju przyszłość może z nich wyrastać. Pierwszą, skromną próbę zestawienia tych przestrzeni czasowych $\mathrm{w}$ połączeniu $\mathrm{z}$ wrażliwością na kwestie międzykulturowe można zaobserwować w opowiadaniu Palma-christi (Cudowny olejek [olej rycynowy]), włączonym do zbioru opowiadań L'Afrique qui vient opublikowanego w 2013 roku $^{12}$. Niezależnie od przenikliwości niektórych refleksji (jak ta poświęcona postrzeganiu kwestii adopcji białoskórych dzieci przez osoby czarnoskóre), błyskotliwości w obrazowaniu współczesnej bizneswoman (która wykorzystuje znajomości na Karaibach do nabywania cudownych produktów do włosów dla paryskich klientek), rozpoznania autorki wskazują przede wszystkim na doświadczenie zagubienia bohaterów w wielokulturowym świecie, w którym coraz trudniej o podtrzymanie więzi rodzinnych i przekazu tradycyjnej wiedzy. Jej komercjalizacja stanowi w świecie afropejskim jedyne możliwe rozwiązanie, co nie zaspokaja zapotrzebowania społecznego. Miano zdaje się tu podważać potencjał przyszłości afrykańskiej rozproszonej na wszystkie kontynenty, wchodząc $\mathrm{w}$ polemikę $\mathrm{z}$ afrooptymistyczną wizją literatury pokolenia migritude (współczesnych obywateli świata pochodzenia afrykańskiego, określonych mianem stworzonym na wzór pojęcia négritude przez Jacques'a Chevriera) ${ }^{13}$, dla którego

[o]d teraz, żeby zrozumieć Afrykę, należy odszukać wszystkie jej drobne okruchy rozrzucone na świecie. Dawniej literatura afrykańska głosiła: „Odwołuję się do moich korzeni”, dziś to nie tylko korzenie, lecz także pień i liście rozrzucone przez wiatr ${ }^{14}$.

Poszukiwania filozoficzne i literackie kameruńskiej pisarki zbiegają się w tym czasie z rozważaniami innych francuskojęzycznych humanistów i artystów oraz odradzającym się światem wyobrażeń afrofuturystycznych. Jeszcze w latach 90. XX wieku Mark Dery diagnozuje niepopularność gatunków fantastycznych w anglojęzycznych literaturach afrykańskich i afrykańskiej diaspory, przyczyniając się jednocześnie do rozpowszechnienia koncepcji afrofuturyzmu w literaturoznawstwie. Badacz określa wówczas tym terminem zjawiska artystyczne zawłaszczające rozwiązania technologiczne i przedstawienia charakterystyczne dla fantastyki w sztuce

Mbembe przedstawia Alice Lefilleul. Por. A. Lefilleul, Afropéanisme, identités frontalières et afropolitanisme: Penser les nouvelles circulations, „Africultures” 2014, nr 99-100, s. 84-91.

12 Por. przyp. 5.

13 Za: S. Lavigne, La migritude: Une errance identitaire et littéraire?, „Equinoxes: A Graduate Journal of French and Francophone Studies" 2007-2008, nr 10, jesień/zima, [online] https://www.brown. edu/Research/Equinoxes/journal/eqx10 index.html (dostęp: 15.08.2021).

14 A. Mabanckou, cyt. za: A. Mrowińska, Jaka twarz z tego rozbicia? O tożsamości wypracowywanej na nowo przez pokolenie afrooptymistów [w:] K. Bolęba-Bocheńska, M. Błaszkowska (red.), Twarz - maska-wizerunek, Wiele Kropek, Kraków 2018, s. 59-60. 
afroamerykańskiej ${ }^{15}$. Afrofuturyzm w tej postaci zahacza jednak częściowo o starszą, bo sięgającą XIX wieku, tradycję ,czarnego pisarstwa utopijnego” (ang. Black utopia), którego historii oraz uwikłaniom ideologicznym przygląda się Alex Zamalin w opracowaniu Black Utopia: The History of an Idea from Black Nationalism to Afrofuturism ${ }^{16}$. Autor, za Derym, wyróżnia utopijne i dystopijne prace drugiej połowy XX wieku takich pisarzy, jak Samuel R. Delany, Octavia E. Butler, którzy zainspirowali nowe pokolenia do „rewidowania historii i kreowania niemożliwych trajektorii czarnej wolności" ${ }^{17}$. Zamalin konkluduje, że nawet teksty o charakterze utopijnym pod piórem twórców afroamerykańskich wyróżniają się krytycznością spojrzenia i tragizmem wpisanym w fikcjonalne światy w większym stopniu niż w przypadku ich literackich poprzedników wywodzących się ze świata Europy Zachodniej ${ }^{18}$.

Na gruncie takiej wyobraźniowości rodzą się kolejne obrazy przedstawiające fantastyczną przyszłość Afryki, jak dzieje się to w przypadku Nigerii w wyniku kontaktu z przybyszami z kosmosu w powieści Nnedi Okorafor Laguna ${ }^{19}$ bądź Trynidadu ujętego przez Anthony'ego Josepha w tunel czasowy łączący przeszłość z przyszłością w poetyckiej prozie Afrykańskie korzenie $U F O^{20}$. Zanim jednak w tak zarysowanej przestrzeni literackiej mogła pojawić się Rouge impératrice Léonory Miano z jej nie-utopijnym rozpoznaniem afrykańskiej przyszłości, na kształt afrofuturyzmu w wydaniu frankofońskim wpłynęły dwa teksty. Pierwszy z nich, autorstwa Felwine'a Sarra, senegalskiego intelektualisty, historyka i ekonomisty, to Afrotopia, wydany w 2016 roku esej wzywający do emancypacji wyobrażeń o Afryce i odcięciu od prerogatyw wysuwanych przez zachodnią myśl filozoficzną, społeczną i gospodarczą. Według Sarra wyzwaniem dla współczesnych artystów i filozofów afrykańskich powinno być wypracowanie ,własnych metafor przyszłości” ${ }^{21}$, w pełnej niezależności intelektualnej i odwadze odpowiedzialnego projektowania tego, co nadchodzi ${ }^{22}$.

Drugą z książek, pozornie łatwą do zestawienia z koncepcją Katiopy w wydaniu Miano, stanowi dystopijna powieść Abdourahmana A. Waberiego Aux États-Unis d'Afrique, opublikowana 10 lat wcześniej niż głośny tekst Sarra. Wywodzący się z Dżibuti pisarz i intelektualista powołuje w niej do życia Stany Zjednoczone Afryki, z przenikliwością, satyrycznie i przewrotnie przedstawiając przyszłe odwrócenie ról między ubożejącą i podupadającą Europą oraz Ameryką Północną, których

15 M. Dery, Black to the Future: Interviews with Samuel R. Delany, Greg Tate, and Tricia Rose [w:] M. Dery (red.), Flame Wars: The Discourse of Cyberculture, Durham-London 1994, s. 179-180.

16 A. Zamalin, Black Utopia: The History of an Idea from Black Nationalism to Afrofuturism, Columbia University Press, New York 2019.

17 Oryg. ,[Black American texts than both] revise history and imagine impossible trajectories of black freedom". Ibidem, s. 10.

18 Ibidem, s. 12.

19 N. Okorafor, Laguna, przeł. A. Studniarek, Wydawnictwo Mag, Warszawa 2015.

20 A. Joseph, Afrykańskie korzenie UFO, przeł. T. Tyszowiecka blasK!, Korporacja Ha!art, Kraków 2020.

21 F. Sarr, za: S. Kodjo-Grandvaux, op. cit.

22 F. Sarr, Afrotopia, Philippe Rey, Paris 2016, s. 17 i passim. 
mieszkańcy usiłują emigrować do prosperującej, ekonomicznie dominującej nowej Afryki. Autor ukazuje jednak, że zmiana układu sił w sieci imperialnych relacji prowadzi nieuchronnie do zepsucia ideałów i wyczerpania kulturowego, które nie może przysłużyć się odnowie ani kontynentu afrykańskiego, ani świata w jego obecnej postaci $^{23}$.

W kontekście wyżej wymienionych inspiracji literackich i filozoficznych oraz zainteresowań i pisarskich skłonności Miano jej wizja przyszłości afrykańskiej jednocześnie wyrasta z propozycji afrofuturyzmu oraz czarnych utopii, jak i je przekracza. Jeśli rozumieć nurt afrofuturystyczny jako próbę zerwania z ograniczającą potencjał Afryki teraźniejszością i znalezienia na gruncie jej kultur narzędzia do przeniesienia jej w lepszą, a przynajmniej bardziej technologicznie rozwiniętą przyszłość, to Rouge impératrice, częściowo wypełniając tę wizję, odnajduje zakorzenione w rzeczywistości XXI wieku zjawiska i przesłanki do tego, by Afryka w nowym kształcie mogła nadejść. Jednocześnie wyraźna niechęć autorki do idealizacji i esencjalizacji tożsamości i zjawisk przynależnych światu subsaharyjskiemu uniemożliwia jej stworzenie literackiej utopii, która zawierałaby propozycję doskonałej przyszłości. Dla kameruńskiej powieściopisarki proces wyzwalania narracji z wiążących ją kategorii stanowi podstawowy mechanizm prowadzący do odkrywania, rewidowania i utrwalania głosu tożsamości, także kulturowej, którą chciałaby reprezentować ${ }^{4}$. Praca związana z uwalnianiem wyobraźni i sposobów literackiego przedstawiania staje się dla Miano tak istotna, że autorka ze sceptycyzmem podchodzi do rozumienia i oczekiwań wiązanych z afrofuturyzmem:

W afrofuturyzmie przeszkadza mi właśnie termin futuryzm. Futuryzm stanowi europejski prąd literacki o swoistych zasadach. Nie sądzę, by wystarczyło dodać do niego przedrostek „afro” bądź jakiś inny, żeby pojęcie zmieniło swą tożsamość. Nie zamierzam wyobrażać sobie Afryki, która nie została skolonizowana, która nie doświadczyła transatlantyckiego i transsaharyjskiego handlu ludźmi. Afryka istnieje właśnie pod nazwą „Afryka”, ponieważ te wydarzenia miały miejsce. Nie zamierzam uciekać przed moją historią, interesuje mnie raczej obecnie to, co mogę z nią zrobić25.

23 A. Prabhu, «Aux Etats-Unis d'Afrique» de Abdourahman Waberi: Narration dialogique ou dialectique?, „Euvres et Critiques” 2011, nr 2, s. 79-92.

24 L. Miano, Sub-Saharan Literatures and the Conquest of the Self, „Journal of the African Literature Association" 2014, nr 8 (2), s. 224.

25 Oryg. „Dans afrofuturisme, c'est le terme futuriste qui me dérange. Le futurisme, c'est un courant littéraire européen qui a des codes bien particuliers. Je ne crois pas qu'il suffise de mettre «afro» ou autre chose devant pour que la notion perde son identité. Moi je n'ai pas envie d'imaginer que l'Afrique n'a pas été colonisée, qu'elle n'a pas connu les déportations transatlantiques ni les traites transsahariennes. L'Afrique existe précisément sous le nom «Afrique» parce que ces événements ont eu lieu. Je n'ai pas envie de fuir mon histoire, ce qui m'intéresse surtout aujourd'hui, c'est voir ce que je peux en faire". L. Miano, cyt. za: Y. Lagarde, L'afrofuturisme, une esthétique de l'émancipation, „France Culture”, 6.09.2019 [online], https://www.franceculture.fr/design/lafrofuturisme-uneesthetique-de-lemancipation (dostęp: 15.08.2021). 
Za zadanie stawia sobie ona raczej - niezależne od cudzych dyskursów - tworzenie języka, który umożliwi wyrażenie potencjału kontynentu i jego społeczności. By móc zobrazować powieściową przyszłość z 2124 roku, Miano zdecydowała się na powołanie nowego sposobu opowiadania o Afryce. Nie przekraczając gramatyki i poetyki języka francuskiego, autorka stara się raczej doprowadzić do jego wzbogacenia o nowe pojęcia, rozumienia i koncepcje. Znana od starożytności europejska nazwa kontynentu afrykańskiego nie pojawia się zatem w powieści ani razu. Kamerunka stosuje w zamian określenia „Kontynent” oraz - wskazujące na nową rzeczywistość polityczną i administracyjną - „Sojusz” (oryg. Alliance) oraz „Katiopa". Ostatni z nich stanowi termin przewodni, określając istniejący od pięciu lat w powieściowej czasoprzestrzeni polityczny byt jednoczący niemal wszystkie dawne państwa afrykańskie (z wyjątkiem krajów Maghrebu i czterech niedających się wchłonąc do wielkiej unii państw Afryki Wschodniej). Wywodzi się z języków kikongo i, jak zaznacza autorka, żadne z afrykanizowanych i odeuropeizowanych pojęć nie zostały przez nią wymyślone, lecz funkcjonują one w przynajmniej jednym lub kilku językach afrykańskich ${ }^{26}$. Decentralizacja procesu nazywania funkcjonujących w światowym obiegu bytów i zjawisk dotyczy także innych krajów. Z wprowadzonych kontekstów historyczno-kulturowych lub towarzyszącego powieści słowniczka zamieszonego na końcu książki czytelnik dowiaduje się, że Bhârat to wywodząca się z sanskrytu nazwa Indii, Kiskeya oznacza Haiti w języku rdzennych Indian Taino, a Chosŏn, Hanguk i Zhōnghuá to chińskie i koreańskie określenia Korei Północnej, Korei Południowej oraz Chin. Mechanizm oddawania nazw terytoriów w językach rodzimych nie znajduje jednak zastosowania w przypadku krajów Europy i ich rzeczywistości. Ona sama jest obecna w tekście jako Pongo, co w języku duala oznacza „północ” i określa Stary Kontynent, jak przyznaje w wywiadzie autorka, z perspektywy działania dokonanego przez imperia europejskie wobec Afryki, które przybyły do niej przez morze właśnie z północy ${ }^{27}$. W podobnym geście Ameryka Północna zostaje określona mianem „zachodu”, czyli wywodzącym się z języków Afryki Zachodniej pojęciem Mbenge. Zmiana perspektywy nazywania świata $z$ byłego centrum do byłych peryferii wskazuje na odwrócenie układu sił politycznych i kulturowych, utratę dominacji ekonomiczno-kulturowej, potwierdzającą się w przytoczonych wydarzeniach. Miano bowiem rozpoczyna swoją nie-utopię od wydarzenia postapokaliptycznego, jakie stanowi północnokoreański atak nuklearny na dawne Stany Zjednoczone, a na terenach Pongo, w tym Fulasi (francuskich) - bliżej niewyjaśniona Krzywda (Sinistre), związana z przeludnieniem kontynentu, wzrostem cen ropy oraz upadkiem gospodarczym i kulturowym dawnych mocarstw. W wyniku tej degradacji wielu mieszkańców Europy emigrowało do Katiopy, poszukując w niej lepszego miejsca do życia. Społeczności potomków europejskich osadników, którzy

26 Por. L. Miano, L'Afrique a aussi le droit d'incarner l'amour, „Mediapart”, 18.09.2019 [online], https:// www.youtube.com/watch?v=O2kINlv9UiM\&t=863s\&ab_channel=MediapartMediapart (dostęp: 15.08.2021).

27 Ibidem. 
nie wykazują woli asymilacji w nowym państwie, wzorowane być może na afrykanerskich enklawach w RPA (ze względu na ich przywiązanie tożsamościowe do kraju pochodzenia przodków oraz ich fizyczną i geograficzną izolację), są zbiorowo określane jako Pokrzywdzeni (Sinistrés). Miano w ten sposób przepisuje XXI-wieczne doświadczenia uchodźczych czy migracyjnych mniejszości jako zapowiedź przyszłości Europejczyków - Portugalczyków, Francuzów, w których krajach nie dało się utrzymywać dłużej XX- i XXI-wiecznego, europejskiego stylu życia. Zmuszeni przez to do emigracji, udali się do pozostałości odizolowanych, zamkniętych wspólnot europejskich na terenach dawnych kolonii, gdzie wciąż liczyli na powrót do przemijających przywilejów, a ich „oddalenie [od Europy] jedynie pogłębiało przywiązanie do raju utraconego" 28 .

Utrata pozycji władzy przez Europę przedstawia się w powieści nie tylko jako wynik wzmiankowanej katastrofy ekologicznej i ekonomicznej, ale także jako skutek nieumiejętności rozpoznania nieuchronnych przekształceń w układzie światowych sił politycznych i kulturowych. Byli kolonizatorzy

[p]rzejęci samymi sobą, nie mogli zrozumieć otaczających ich wtedy rozgrywek, postrzegając konceptualny etap Chimurengi [walki o niepodległość - przyp. A.M.] wyłącznie jako nagromadzenie minionych dyskursów, tysiąckrotnie przemielonych i przestarzałych. Znali przecież na pamięć ciągnącą się skargę potomków deportowanych skazanych na niewolnictwo, lamenty wnuków skolonizowanych przodków. Jak dotąd, z tych płaczów nie wynikło nic poza literaturą niezrozumiałą dla mas, które chciała celebrować, i odrobiną muzyki, nic, co mogłoby zmienić świat ${ }^{29}$.

Powyższy cytat, zaczerpnięty z fragmentu przybliżającego w formie mowy pozornie zależnej punkt widzenia „czerwonej kobiety”, wypunktowuje pogardę Europejczyków dla konceptów i opowieści pochodzących spoza granic ich świata, identyfikuje źródła poczucia wyższości, na jakie mieszkańcy byłego centrum zostali historycznie skazani, oraz krytykuje dotychczasową rolę literatur subsaharyjskich w kształtowaniu nowoczesnej tożsamości afrykańskiej. Wyraźna staje się tu próba obiektywizacji i uniwersalizacji przemyśleń autorki o historii. Wielokrotnie dystansuje się ona w tekście od afrocentryzmu, uznając go za wadliwą propozycję nowego porządku, polegającą na odwróceniu tego, co było, bez możliwości przemiany relacji społecznych i międzynarodowych. Jednocześnie zaznacza istotność tworzenia nowych narracji, niemal w odpowiedzi na filozoficzne wezwanie Sarra, i ich niezbędność w procesie wyobrażania i powoływania do życia nowej rzeczywistości - w tej

28 Oryg. „Cet éloignement ne faisait que renforcer l'attachement au paradis perdu”. L. Miano, Rouge impératrice, op. cit., s. 17.

29 Oryg. „Imbus d'eux mêmes, ils n'avaient pas compris ce qui se jouait alors, la Chimurenga conceptuelle ne leur apparaissant que comme une compilation de discours écoulés, mille fois rabâchés. Ils connaissaient par cœur la longue plainte des descendants de déportés réduits en esclavage, les gémissements des petits-fils de colonisés. Jusque-là, ces lamentations n'avaient produit qu'une littérature inaccessible aux masses qu'elle voulait célébrer, un peu de musique, pas de quoi changer le monde". Ibidem, s. 72-73. 
pogardzanej pierwotnie literaturze narrator upatruje pierwszy, przeoczony przez wielkich graczy starego świata, sygnał nadchodzących zmian.

Pojawiająca się w tekście Chimurenga to wywodzący się z języka shona termin oznaczający rewolucyjny opór wobec dominacji brytyjskiej w Afryce Południowej. Powieść sugeruje, że przed możliwym powstaniem zjednoczonej Katiopy musiało dojść do kilku etapów tego procesu, a pierwszy z nich stanowiła Chimurenga pojęciowa, nieuniknione przejmowanie narracji o najważniejszych wydarzeniach historycznych i politycznych dotyczących Afryki. Kolejnym ważnym zjawiskiem, którego dotyczy odzyskiwanie procesów nazywania, jest Maafa, synonim handlu transatlantyckiego i deportowania niewolników, zaczerpnięty z języka suahili. Można go uznać za symboliczny dla opisywanej strategii, służącej nazywaniu na nowo $\mathrm{z}$ afrykańskiego punktu widzenia i tworzenia nauki. Innym, nie mniej istotnym celem tego procederu jest umożliwienie odtwarzania i przetwarzania pamięci. Jej rola w narodzinach prosperującego państwa zjednoczonej Afryki okazuje się w ujęciu Miano kluczowa. Katiopę w 2124 roku wypełniają i współtworzą znaki historii i zjawiska ją przywołujące. W stolicy tego nowoczesnego państwa, Mbanzie, wykorzystano dwa wielkie parki dla uczczenia pamięci osobno przodkiń i przodków, szczególnie tych, których stracono w czasie Maafy i których miejsca pochówku pozostają nieznane. Zwano je „ogrodem naszych matek” (le jardin de nos mères) oraz „doliną naszych ojców” (la vallée de nos pères) - „ci, którzy potrafili słuchać, nawiązywali w nich kontakt z mową drzew, które przechowywały więcej wiedzy niż tomy historyczne" ${ }^{30}$.

Inny ślad pracy pamięci w państwie Katiopa stanowi osobiste przywiązanie jego obywateli do odległych wydarzeń historycznych, niewątpliwie inspirowane rolą, jaką historia odgrywa w postkolonialnym jednoczeniu społeczności państw afrykańskich. Ilunga, przewodniczący zjednoczonej Afryki, czyli „mokonzi”, i drugi z pary głównych bohaterów powieści, wspomina inicjacyjny rytuał wejścia w okres dojrzałości. Towarzyszyło mu odgrywanie historycznego przedstawienia jako praktyki żywej mowy związanej z życiem Gaspara Yanga, Afrykanina deportowanego do Meksyku na przełomie XVI i XVII wieku, który po ucieczce i wyzwoleniu się ze statusu niewolnika założył pierwsze wolne miasto czarnych, znane jako Yanga w Veracruz ${ }^{31}$. Z kolei tytułowa „czerwona kobieta”, Boya, nosi imię wymyślone przez jedną ze swych przodkiń na podstawie zasłyszanego i zapamiętanego imienia dawnej afrykańskiej królowej. Jej rodzina wiedziała tylko tyle, że babka przekształciła je, nadając mu nowoczesne brzmienie i jednocześnie wprowadzając do swego rodu w pełnej formie imienia Boyadishi potencjał kobiecej siły. Bohaterka została więc wyróżniona symbolem władzy, który „(...) ma doprowadzić do odnowienia dzieła Nana Buruku, ponownych narodzin świata, zauważył [Ilunga]" 32 . W tej intymnej rozmowie dwojga kochanków siła ich relacji zawiązuje się dzięki wspólnemu zauważeniu i zgłębieniu

30 Ibidem, s. 60.

31 A.M. Martinez, Ch.H. Rowell, M. Jones, A. Martinez, Interview with Andres Maceda Martinez, „Callalo” 2008, 31 (1), Winter, s. 12 i passim.

32 L. Miano, Rouge impératrice, op. cit., s. 53-54 (pisownia i wyróżnienie oryg.). 
ważnej symboliki transafrykańskiej, w tym przypadku bogini Nana Bùrúkù - tej, która jako jedna z patronek-opiekunek życia rodzi z siebie cały wszechświat ${ }^{33}$.

W wizji Afryki, która nadchodzi, zawartej w Rouge impératrice, uwzględniono zatem także przestrzeń do rozwoju duchowości, tego, co wydaje się nieracjonalne, jako niezbędnego fundamentu ustanawiającego etyczne zasady istnienia i funkcjonowania Katiopy.

Katiopa słynęła ze swej akceptacji irracjonalnego wymiaru życia, przywiązania do kontaktu z niewidocznym, zdolności do nawiązywania z tym wszystkim relacji bez konieczności zmiany w coś innego. Od czasów pierwszej Chimurengi myśliciele i mistrzowie ezoteryzmu usiłowali, każdy w swojej dziedzinie, położyć kres wewnętrznemu przemieszczeniu, które oddalało duszę od społeczeństwa, rozrzucając jej fragmenty na cztery strony świata ${ }^{34}$.

Wymiar ezoteryczny afrykańskiego postrzegania świata realizuje w państwie działalność Rady (le Conseil), zajmującej się uzgadnianiem etyki tradycyjnej z życiem publicznym. Miała ona stać na straży polityki prowadzonej w imię interesu społecznego i wspólnego konceptualizowania świata. Członkowie Rady ucieleśniali dziewięć zjednoczonych regionów Katiopy. Wywodzili się z przedstawicielek i przedstawicieli starszyzny, odznaczających się zdolnościami ponadnaturalnymi, które pozwalały im gromadzić się niezależnie od miejsca przebywania ich codziennych, ludzkich ciał, w celu doradzania przywódcy-mokonziemu w podejmowaniu decyzji na poziomie państwowym i zagranicznym. Istnienie Rady i uznanie jej za jeden $z$ najistotniejszych elementów administracji państwowej uwydatnia dbałość zamysłu Miano o nieustanne poszanowanie praw, interesów, a nade wszystko dobrobytu obywateli.

Polityczny i gospodarczy rozkwit zarówno bierze się, jak i sam ujawnia, w sposobie organizacji architektonicznej, komunikacyjnej i społecznej sojuszu państw afrykańskich w zgodzie ze środowiskiem naturalnym. Na poziomie funkcjonowania miast najważniejszymi rozwiązaniami są: utworzenie licznych placów jako przestrzeni spotkań i wydarzeń życia publicznego, uważnie obserwowanych i wysłuchiwanych przez odpowiednich urzędników nieustannie badających nastroje społeczne w nowo powstałym państwie o złożonej przeszłości i kulturowości; otaczanie budynków tworzonych z naturalnych materiałów jak największą ilością terenów zielonych; ograniczenie ruchu pojazdów innych niż rowery elektryczne i zupełne wykluczenie ich z centrów miast; rozwinięta sieć komunikacji przypominającej tramwaje (baburi) oraz szybką kolej międzymiastową przecinającą z jak najmniejszą ingerencją połacie

33 Za: T.N. Washington, Our Mothers, Our Powers, Our Texts: Manifestations of Ajé in Africana Literature, Indiana University Press, Bloomington 2005, s. 59, 62 i passim.

34 Oryg. „Katiopa était connu pour son acceptation de la dimension irrationnelle de la vie, son attachement aux messages de l'invisible, son aptitude à entrer en relation avec tout cela sans chercher à le transformer. Depuis la Première Chimurenga, penseurs et maîtres en ésotérisme avaient travaillé, chacun dans leur domaine, à mettre fin à la dislocation intime qui avait écartelé l'âme des populations, en dispersant aux quatre vents les morceaux". Ibidem, s. 202. 
lasów równikowych. Szczególnie ciekawym rozwiązaniem stanowiącym przykład uważnego namysłu Miano nad obecną sytuacją miast afrykańskich jest wykorzystanie przewagi ruchu pieszego w centrach wielu stolic i dużych miast ze względu na brak rozwiniętej infrastruktury. Dla autorki stało się to inspiracją do zachowania tej specyfiki codzienności afrykańskiej w postaci unowocześnionej - systemu infrastruktury pieszej, często ruchomej, umożliwiającej bezpieczne i sprawne poruszanie się między odległymi częściami miasta.

Wszelkie futurystyczne i filozoficzne środki, które wykorzystuje Miano do stworzenia projektu potencjalnego, zjednoczonego państwa afrykańskiego, przedstawiane są czytelnikowi stopniowo w rozległej powieści o szczególnym wymiarze psychologicznym. Wyjątkowy zamysł połączenia rozważań na poziomie politycznym i filozoficznym z przeżyciami i przemyśleniami funkcjonujących w tym świecie bohaterów pozwala autorce rozpatrywać różne idee przewodnie, motywy i cele, które towarzyszyłyby powstaniu takiego ustroju politycznego. Dominantą stylistyczną i organizacyjną narracji w całej powieści jest mowa pozornie zależna, opóźniająca i zgłębiająca rozwój wydarzeń poza ich chronologiczną kolejnością, połączona ze szczegółowym, stopniowym odsłanianiem życia, także wewnętrznego, głównych bohaterów i ich postrzegania Katiopy. Ilunga stojący na czele sojuszu zostaje opisany jako bojownik o pokój. Ma on głęboki szacunek do różnorodnych tradycji i zawiłości historycznych społeczności współtworzących zjednoczone państwo, jednocześnie dążąc w ramach obrony suwerenności i solidarności państwowej do pozbycia się z niego jednostek, które nie poczuwają się do uczestniczenia w budowaniu nowej afrykańskiej rzeczywistości, do bycia obywatelem nowoczesnego, złożonego kulturowo kraju. Boya, która zostaje wybranką serca Ilungi, znajduje w sobie więcej zrozumienia dla tych wyrzutków i buntowników kulturowych, którzy z różnych przyczyn, najczęściej historycznych, nie mogą wpisać się w projekt jednolitego państwa łączącego tradycję $\mathrm{z}$ wyzwaniami przyszłości. Trzeci, skrajny, punkt widzenia reprezentuje w powieści pomocnik mokonziego, kalala - głównodowodzący ochrony wewnętrznej i szef stanu o imieniu Igazi. Narracja z jego perspektywy wraz z przedstawieniem powyższych sposobów postrzegania docelowej jedności Katiopy pozwalają uwypuklić różnice i wewnętrzne starcia między odmiennymi siłami, które mogą wspólnie obierać za cel utrwalenie i pogłębienie więzi politycznych i kulturowych wewnątrz kontynentu afrykańskiego mimo sprzecznych motywów i preferowanych metod. Miano rozpoznaje wśród tych przesłanek zarówno strach przed powtórzeniem się historii kolonialnej i zbyt silnymi wpływami Europy na kształtowanie się rzeczywistości afrykańskiej, jak i nienawiść oraz chęć odwetu, a także chęć usprawnienia administracyjnego, które pozwoliłoby na formowanie lepszej przyszłości dla prosperującego państwa i realizujących swoje życiowe cele obywateli.

To przemieszanie i próba połączenia świata polityki, odgórnych decyzji, z życiem intymnym, doświadczeniami duchowymi i cielesnymi, codziennymi, wydaje się stanowić taktykę urzeczywistnienia etyki, która byłaby według kameruńskiej powieściopisarki konieczna do wprowadzenia w życie idei zjednoczenia, wolności, 
zrównoważonego rozwoju jako propozycji odmiennej od projektu XX- i XXI-wiecznej globalizacji. Miano jednak, wbrew powszechnym odczytaniom powieści ${ }^{35}$, nie tworzy Katiopy jako organizacji doskonałej, zaznaczając niesprawiedliwości i nierówności pokutujące w społeczeństwie. Jedną z przesłanek niepozwalających uznać Rouge impératrice za propozycję utopijną stanowi wykluczenie z życia społecznego i pełna inwigilacja Pokrzywdzonych, wobec których różni bohaterowie ujawniają odmienne, często krzywdzące, stanowiska. Według przedstawianej tu interpretacji głos najbliższy stanowiska samej autorki wyraża Boya, naukowczyni, intelektualistka, która jako jedna z niewielu darzy katiopańską mniejszość zrozumieniem i współczuciem. Drugim elementem podważającym zakładaną idealność świata zjednoczonej Afryki jest niewyrażana wprost homofobia, która objawia się w narracji przybliżającej życie Seshamani, pierwszej damy, małżonki Ilungi. Kobieta zmuszona jest do ukrywania swoich homoseksualnych relacji, a związek z władcą Katiopy umożliwia jej nie osobiste spełnienie, lecz pełną ochronę prywatności, często kosztem własnego męża. Miano wykazuje się tu kunsztem literackim, w psychologizującej narracji stopniowo odkrywając przed czytelnikiem złożoność bohaterów powieści i motywacji, którymi się kierują.

Autorka obserwuje afrykańską teraźniejszość z perspektywy historycznej, a jej wzrok przenika do tego, co możliwe bądź nieuniknione, twórczo układając diagnozy rzeczywistości we wzór przyszłych wydarzeń i prawdopodobieństw. Jej głębokie rozumienie zależności między tym, co historyczne, a obecną sytuacją polityczną, społeczną, klimatyczną, gospodarczą, prowadzi do uformowania proponowanej wizji przyszłości. Czytelnik przemierza tę drogę rozumienia wstecz, à rebours - poznając zależności rządzące ową przedstawioną, zaproponowaną przyszłością, ma możliwość innego spojrzenia na teraźniejszość i prowadzącą ku niej historię. Dla Léonory Miano perspektywa afrofuturyzmu pomaga przyjrzeć się bieżącym problemom i proponowanym ich rozwiązaniom społecznym oraz politycznym post factum. Obraz przyszłości krajów afrykańskich nie jest niczym innym niż przenikliwą, a w tej uważności nowatorską analizą obecnych napięć i skłonności, ich możliwych kierunków rozwoju. Wizja tej przyszłości nie niesie w sobie nadziei na rozwiązania nie-z-tego-świata ani uniknięcia wewnętrznych napięć i konfliktów, ma natomiast na celu naświetlenie problemów teraźniejszości i decyzji, jakie wobec nich się podejmuje. Jest to więc przyszłość bliska teraźniejszości, dla wielu czytelników wciąż być może nie do pomyślenia, a jednak dzięki pisarskiej uważności mocno zakorzeniona we wciąż dostępnym dla nas świecie i przez to - jak najbardziej realna.

\section{Bibliografia}

Abomo-Maurin M.-R., Préface [w:] A.D. Tang (red.), L'ouvre romanesque de Léonora Miano: Fiction, mémoire et enjeux identitaires, L'Harmattan, Paris 2014.

35 Por. A. Pétin, op. cit. 
Aguilar R.M., Exhalaisons de la traite et de l'esclavage dans l'œuvre de Léonora Miano, „Woman in French Studies” 2020, nr 8, Special Issue, s. 133-145.

Chaulet-Achour Ch., La force du féminin dans «La saison de l'ombre» [w:] A.D. Tang (red.), L'œuvre romanesque de Léonora Miano: Fiction, mémoire et enjeux identitaires, L'Harmattan, Paris 2014.

Commencement, „The New York Times”, 28.05.1988 [online], https://www.nytimes. com/1988/05/28/nyregion/commencement.html (dostęp: 15.08.2021).

Dery M. (red.), Flame Wars: The Discourse of Cyberculture, Durham-London 1994.

Joseph A., Afrykańskie korzenie UFO, przeł. T. Tyszowiecka blasK!, Korporacja Ha!art, Kraków 2020.

Kodjo-Grandvaux S., Le grand retour de l'utopie africaine, „Le Monde Afrique”, 23.02.2020 [online], https://www.lemonde.fr/afrique/article/2020/02/23/le-grand-retour-de-1-utopieafricaine_6030544_3212.html (dostęp: 15.08.2021).

Lagarde Y., L'afrofuturisme, une esthétique de l'émancipation, „France Culture”, 6.09.2019 [online], https://www.franceculture.fr/design/lafrofuturisme-une-esthetique-delemancipation (dostęp: 15.08.2021).

Lavigne S., La migritude: Une errance identitaire et littéraire?, „Equinoxes. A Graduate Journal of French and Francophone Studies" 2007-2008, nr 10, jesień/zima, [online] https:// www.brown.edu/Research/Equinoxes/journal/eqx10_index.html (dostęp: 15.08.2021).

Le Bris M., Mabanckou A. (red.), L'Afrique qui vient (anthologie), Hoëbeke, Paris 2013.

Lefilleul A., Afropéanisme, identités frontalières et afropolitanisme: Penser les nouvelles circulations, „Africultures” 2014, nr 99-100, s. 84-91.

Martinez A.M., Rowell Ch.H., Jones M., Martinez A., Interview with Andres Maceda Martinez, „Callalo” 2008, nr 31 (1), Winter, s. 12-17.

Miano L., L'Afrique a aussi le droit d'incarner l'amour, „Mediapart”, 18.09.2019 [online], https://www.youtube.com/watch?v=O2kINlv9UiM\&t=863s\&ab_channel=MediapartMediapartZweryfikowano (dostęp: 15.08.2021).

Miano L., Rouge impératrice de Léonora Miano, une fresque de l'amour et de la mémoire, „France Culture”, 30.08.2019 [online], https:/www.youtube.com/watch?v=58cmsCgjZ60\&t=73s\&ab_channel=FranceCulture (dostęp: 15.08.2021).

Miano L., La saison de l'ombre, Pocket, Paris 2013.

Miano L., Rouge impératrice, Pocket, Paris 2019.

Miano L., Sub-Saharan Literatures and the Conquest of the Self, ,Journal of the African Literature Association" 2014, nr 8 (2), s. 219-236.

Mroczkowska-Brand K., Deportowani z życia. Nowe głosy w narracjach literackich i ich kolonialne konteksty, Wydawnictwo Uniwersytetu Jagiellońskiego, Kraków 2017.

Mrowińska A., Jaka twarz z tego rozbicia? O tożsamości wypracowywanej na nowo przez pokolenie afrooptymistów [w:] K. Bolęba-Bocheńska, M. Błaszkowska (red.), Twarz maska-wizerunek, Wiele Kropek, Kraków 2018, s. 53-65.

Okorafor N., Laguna, przeł. A. Studniarek, Wydawnictwo Mag, Warszawa 2015.

Pétin A., La possibilité d'une utopie romanesque pleinement émancipatrice: «Rouge impératrice» de Léonora Miano, „Revue critique de fixxion française contemporaine” 2020, nr 21, s. 95-108.

Prabhu A., "Aux Etats-Unis d'Afrique» de Abdourahman Waberi: Narration dialogique ou dialectique?, „Euvres et Critiques” 2011, nr 2, s. 79-92.

Sarr F., Afrotopia, Philippe Rey, Paris 2016. 
Tang A.D. (red.), L'œuvre romanesque de Léonora Miano: Fiction, mémoire et enjeux identitaires, L'Harmattan, Paris 2014.

Unter Ecker M., Questions identitaires dans les récits afropéens de Léonora Miano, Presses universitaires du Midi, Toulouse 2016.

Washington T.N., Our Mothers, Our Powers, Our Texts: Manifestations of Ajjé in Africana Literature, Indiana University Press, Bloomington 2005.

Zamalin A., Black Utopia: The History of an Idea from Black Nationalism to Afrofuturism, Columbia University Press, New York 2019. 